\section{THE INTERSECTION OF SCIENCE AND ART}

Being able to communicate complicated scientific concepts in a simple, easy to understand way is a skill. Whether through writing, pictures or cartoons, or even sounds and music, making science approachable should be a primary goal. It was for this reason that we launched our first BioTechniques Lab Grammy competition 5 years ago. We were not sure what to expect from a contest that would feature science parody videos, but we saw it as an opportunity for scientists in the lab to communicate to the world, through a catchy song or two, what they study or what life in the lab is really like.

The Lab Grammy started slowly, with only a handful of entrants that first year. But there was such strong interest in these videos among BioTechniques readers that we decided to continue the contest. To our delight, each ensuing year has resulted in more entrants and far more views of their videos. During our 2016 competition, which ended in February, thousands came to look at the 14 nominees and vote for their favorites.

As the Lab Grammy contest has grown over the years, we have also been quite surprised to see some repeat contestants. In fact, this year's Education Video winner Erez Lieberman Aiden from Baylor College of Medicine also took home the prize in 2015 in same category. For 2016, Aiden's team pulled together a video called "How does DNA fold?" To get insights on how and why Aiden's team created the winning entry, check out our behind the scenes story "And the 2016 Lab Grammy winner is..." (www.biotechniques.com/news/363161).

The Education Video category is actually new to the Lab Grammys; it was our Parody Video category that launched the competition. In 2016, 10 videos competed in the parody category-and after carefully tabulating thousands of votes, the winner was revealed to be "We Found Drugs" by Andrew van der Vaart and Joanna Jacob from Virginia Commonwealth University, a parody of the Rihanna song "We Found Love" (www.biotechniques.com/news/363267).

We would like to thank everyone involved in the Lab Grammy contest; your videos affirm how wonderfully creative scientists can be. Mingling science, art, and pop culture reminds us that although research is rigorous, detailed, and demanding, when communicated with a touch of creativity, it can also become uniquely engaging. Please send your comments to bioeditor@biotechniques.com.

And check out the 2016 videos at www.biotechniques.com/news/362856.

BioTechniques is a peer-reviewed journal dedicated to the publication of original laboratory methods, related technical tools, and methods-oriented review articles that are of broad interest to scientists engaged in basic and applied life science research. Complete Instructions for Authors are available at bt.EditorialManager.com, BioTechniques' website for online manuscript submission. All manuscripts should be submitted at this site.

\section{BioTechniques Staff}

Editorial, Production \& Circulation

Editor-in-Chief: Nathan S. Blow, Ph.D.

Managing Editor: Amy R. Volpert

Senior Editor/Commercial Editor: Patrick C.H. LO, Ph.D Senior Editor/News Editor: Kristie Nybo, Ph.D.

Contributing Writers:

Jeffrey M. Perkel, Ph.D., and Sarah A. Webb, Ph.D.

Production and Creative Manager,

BioScience Group: Genevieve McCarthy

Marketing Manager,

BioScience Group: Damon Mastandrea

\section{Sales \& Business Offices}

Publisher: Tamaryn Hankinson, tamaryn.hankinson@informa.com

Director, Operations and Audience Development, BioScience Group: Nora Pastenkos

Global Sales Director/East Coast: Cheryl Wall, 978-356-0032 cwall@biotechniques.com

Midwest: Bob Zander, 312-925-7648

bob.zander@informausa.com

West Coast: Kayla McCutchan, 212-652-2667

kmccutchan@biotechniques.com

Europe/Asia/Latin America: Rehemah Santiago, +44 (0) 2075519426 rehemah.santiago@informa.com

Manager, Advertising and Production Services,

BioScience Group: Christine Briglia, christine.briglia@informausa.com List Rental: Amy Miller • amiller@ibcusa.com

Reprints: biotechniques@fosterprinting.com

For subscriptions and inquiries, contact:

Phone: (847) 763-4930 Toll-free: (877) 232-2399

Email: biotechniques@halldata.com

\section{EditorialBoard}

Bill Brizzard, Indiana University Research and Technology Corp.

Bruce Budowle, UNT Health Science Center

Piotr Chomczynski, Molecular Research Center

Rita R. Colwell, University of Maryland-College Park and Johns Hopkins University

Joshua J. Coon, University of Wisconsin-Madison

Manel Esteller, Spanish National Cancer Centre (CNIO)

Jeffrey Felton, Western University of Health Sciences

Ron M. Fourney, Royal Canadian Mounted Police

Ivar Giaever, Rensselaer Polytechnic Institute

Richard A. Gibbs, Baylor College of Medicine

Erica A. Golemis, Fox Chase Cancer Center

Peter M. Gresshoff, The University of Queensland

Yoshihide Hayashizaki, RIKEN

Jörg Hoheisel, German Cancer Research Center

Leroy Hood, Institute for Systems Biology

Paul Keim, Northern Arizona University

Pui-Yan Kwok, University of California, San Francisco

Rachael L. Neve, Massachusetts Institute of Technology

Peter J. Oefner, University of Regensburg

Stephen W. Paddock, University of Wisconsin-Madison

Scott D. Patterson, Amgen, Inc.

Leonard F. Peruski, Jr., Centers for Disease Control

John Quackenbush, Harvard School of Public Health

Joshua Z. Rappoport, Northwestern University School of Medicine

Pier Giorgio Righetti, Polytechnic University of Milan

John Rossi, City of Hope

Herbert P. Schweizer, Colorado State University

Jay Shendure, University of Washington

Barton Slatko, New England Biolabs

Steve S. Sommer, MEDomics, LLC

Igor Stagljar, University of Toronto

Mathias Uhlén, The Royal Institute of Technology

Timothy Veenstra, SAIC-Frederick, Inc.

Kent E. Vrana, Penn State College of Medicine

Michael Weiner, AxioMx 